\title{
ANALYSIS OF HEAVY METALS IN SOIL OF SELECTED INUNDATION AREA OF THE NITRA RIVER
}

\author{
Jozef Straňák, Zuzana Pucherová, Andrej Píš, Marcela Domčeková, Iveta \\ Vrábelová, Katarína Ličková, Štefan Straňák, Maroš Záhorský, Kristína Šlágorová
}

\begin{abstract}
Research was aimed at detection of actual state of contamination throughout monitored indicators - heavy metals and $\mathrm{pH}$ values in soil samples of model area of the Nitra river. It analyses and evaluates recorded values of determined elements and soil $\mathrm{pH}$, and following comparison of these values with limit values of current effective legislation. In the inundated area of the Nitra River, we evaluate concentration contents of heavy metals: $\mathrm{As}, \mathrm{Co}, \mathrm{Cr}, \mathrm{Cu}, \mathrm{Hg}, \mathrm{Ni}$, $\mathrm{Pb}, \mathrm{Zn}$ by way of appropriate analytic methods (dissociation in aqua regia) and $\mathrm{pH}$ values in $\mathrm{KCl}$ solution. In our area of interest, based on the soil samples analysis, contamination of following elements $\mathrm{Cd}, \mathrm{Cr}, \mathrm{Ni}, \mathrm{Pb}$ was found. Based on gained results and available knowledge we identify the most probable origins of contamination and we also design measures for improvement of recent state.
\end{abstract}

Keywords: soil, Nitra River, contamination, heavy metals, soil pH

\section{Introduction}

Human activities unconsciously and/or consciously interfere with biotic and abiotic components and processes in environment, mostly with negative effects (Havrlant, Buzek, 1985). Negative effects may show in threatening of quantitative and qualitative characteristics of landscape components and elements. Regarding contamination of the hydrosphere, human brings into the water foreign substances, mainly chemical, organic, petroleum products, metals etc. Regarding contamination of the pedosphere, human brings into the soil contaminants or more precisely hazardous substances through fertilizers, wastes and various chemicals (Wittlinger, Kotlas, 1999). Soil is a live layer of the Earth laying above the bedrock and it enables the life on the Earth. The Council of Europe Recommendations on Soil Protection (1992) defines the soil as an integral part of Earth's ecosystems, situated between the Earth's surface and bedrock. The soil is characterised as a complex and dynamic system (Sousa et al., 2008). It consists of weathered minerals, organic matter, liquids and gases (Mudgal et al., 2014). It is composed of organic and mineral components (Hraško, Bedrna, 1988). Nowadays, soils in Slovakia are exposed to the contamination originating mainly from anthropogenic activity. Hanušin et al. (2000) defines pollution as bringing of physical, chemical and biological substances into the environment, which character and quantity 
disrupt its optimal state. Human activities undesirably enrich the soil with various substances, that is namely dangerous elements and organic pollutants that are contaminants (Volter et al., 2011). Dangerous substances - contaminants get into the soil via natural and anthropogenic processes. The most dangerous contaminants are called "heavy metals", which are also called dangerous trace elements (Styk, 2001). Heavy metals are known as one of the main sources of the environment pollution (Sastre et al., 2002). Issue of the contamination came to the fore already with the arrival of the Industrial Revolution (Zhenli, Xiaoe, Stofeella, 2005). Heavy metals can be found in the soil in various concentrations, oxidation states and bonds (Cances et al., 2003). Jones et al. (2008) define the contamination as the accumulation of polluting substances in the soil above the certain level, what causes degradation or loss of one or more soil functions. The soil contamination has significantly grown in the last decades (Pascucci, 2011). The soil contamination by heavy metals is one of the most serious environmental problems that significantly increase danger of the negative effect on the human population and ecosystems (Abou-Shanab, Angle, Chaney, 2006). Healthy soil can preserve biological productivity, maintain environment quality and foster the health of fauna and flora (Hernandez-Soriano, 2012).

\section{Characteristics of the model area}

The length of the Nitra River is $168.4 \mathrm{~km}$, average width of the river basin is $26.7 \mathrm{~km}$ and its hydrological characteristic is 0.16 what indicates its elongated shape (Figure 1). Total length of river network in basin is $3655 \mathrm{~km}$ and density is $0.81 \mathrm{~km}^{2}$. Nitra River basin surface is $5144 \mathrm{~km}^{2}$. Before its relocation it aligns the Žitava River from the left. The most known tributaries of the Nitra River are the Handlovka $176 \mathrm{~km}^{2}$, the Nitrica $319 \mathrm{~km}^{2}$, the Bebrava $631 \mathrm{~km}^{2}$, the Radošinka 385 $\mathrm{km}^{2}$, the Žitava $906.7 \mathrm{~km}^{2}$ and the Dlhý kanál $428 \mathrm{~km}^{2}$. The Nitra River is one of the most contaminated rivers in the Slovak Republic according to both chemical and ecological evaluation of its quality. Monitored areas are situated in the southeast part of cadastral area of Topol'čany city and southern part of cadastral area of Nitrianska Streda village. Both areas are located in the west Slovakia and belong to Nitra Self-governing Region (Figure 2).

Figure 1: Model area

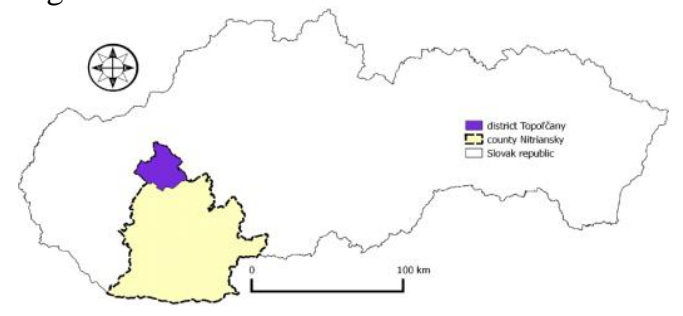


Figure 2: Nitra River

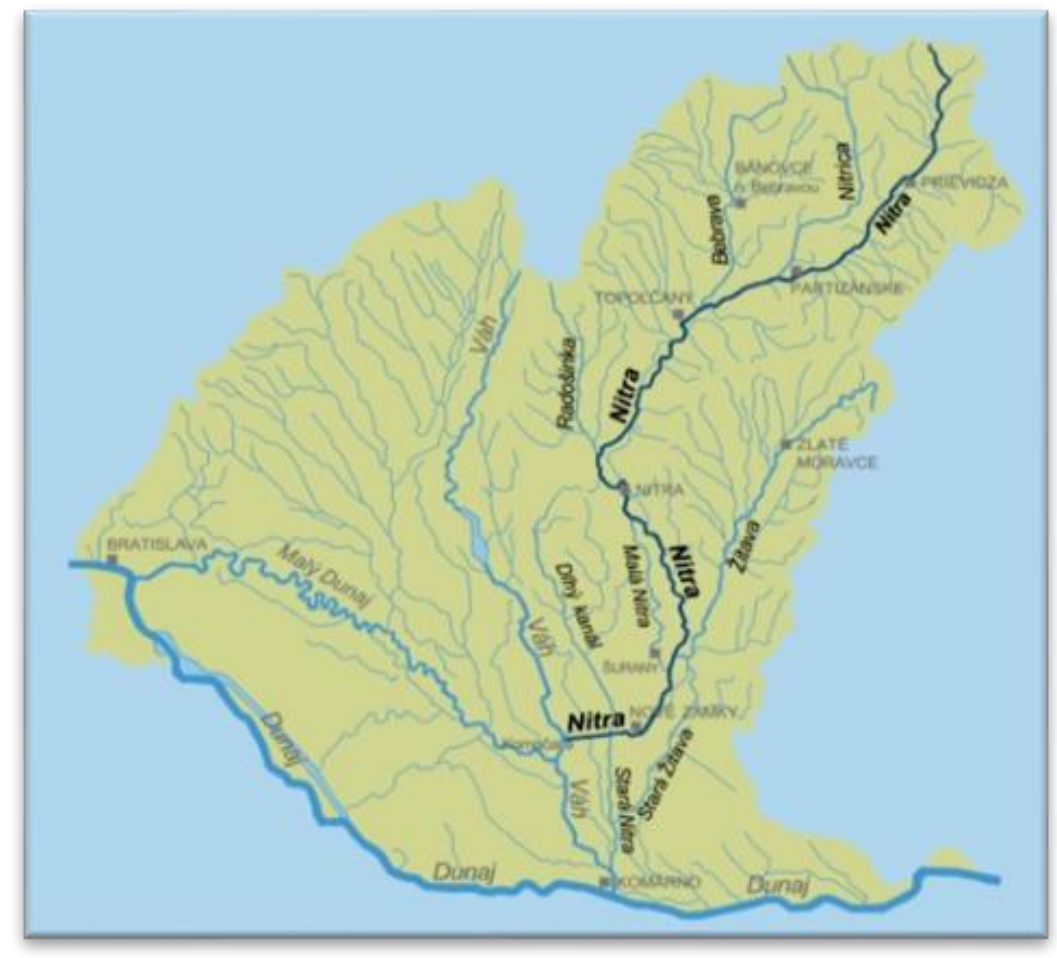

From the viewpoint of down-slope and exposition, monitored area characteristic is plain land without any or with possibility of surface erosion (up to $3^{\circ}$ ). Soil is without skeleton (content of skeleton up to $0.6 \mathrm{~m}$ is under $10 \%$ ). From the viewpoint of the soil depth, soils are deep (60 $\mathrm{cm}$ and more). This information about the soil relate firstly to agricultural soil in the vicinity of the monitored area. Based on the soil sampling in three localities, the soil type was determined as sandy loam soil (according to and BPEJ codes). Most of the negative effects on the studied area caused by humans are from the agricultural activities, whether there are effects from of the vicinity or wider environs of monitored localities. In immediate vicinity of model area is intensively cultivated land. Studied localities are located on the river berm with permanent grass cover and grooves of bottomland woods (Figure 3, Figure 4). The most significant branches within the secondary sector are food and wood processing industry. Some ecological crashes took place at Nitra River, in the past (in 60s). Industrial and communal waste waters were drained into the river. Main pollutants at the upper stretch of Nitra River are water discharging and wastewater treatment plants, Inc. SVS, mines in 
Handlová, Prievidza and Nováky, and within the primary sector it is agricultural activity in monitored localities.

\section{What did we observe?}

In this paper we look for answers on questions about potential contamination of soils in monitored localities and try to define possible factors which may have an effect on contamination of selected elements. We tried to find answers on following questions:

1. Is the soil of monitored localities contaminated by selected heavy metals?

2. If yes, what factors may have possible effect on this contamination?

3. What measures can be suggested for the improvement of the soil state in monitored localities at inundated area of Nitra River?

Figure 3: River Nitra in locality

Topol'čany

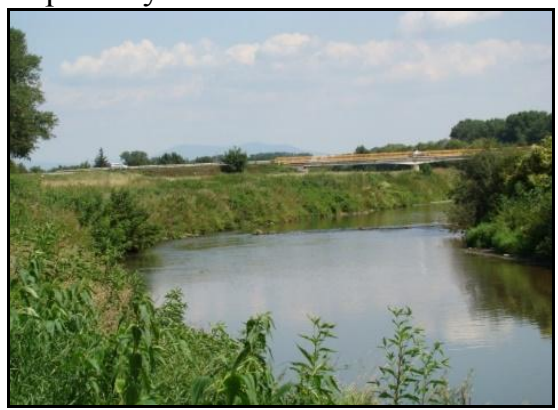

Photo: M. Gális, 2014
Figure 4: River Nitra in locality

Nitrianska Streda Topol'čany

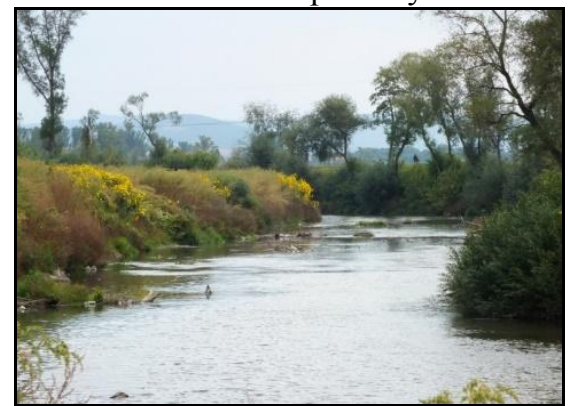

Photo: J. Straňák, 2014

\section{Materials and Methods}

We chose "inundated area" (area of river bed) of Nitra River with the length approx. $2 \mathrm{~km}$. Area was monitored in 3 localities where soil samples were taken, for each locality separately. Samples were taken on at once in two intervals on March 2014 - P1, P3, P5 and on September 2014 - P2, P4, P6 (at vicinity of Nitra River bed). Time range was estimated for 6 months because of fluctuation of concentration values of monitored elements in soil samples and method for determination of heavy metals in soil samples was also took into consideration. It as taken 6 samples overall which were marked appropriately as P1 to P6 (Figure $5)$. 
Figure 5: Monitored localities

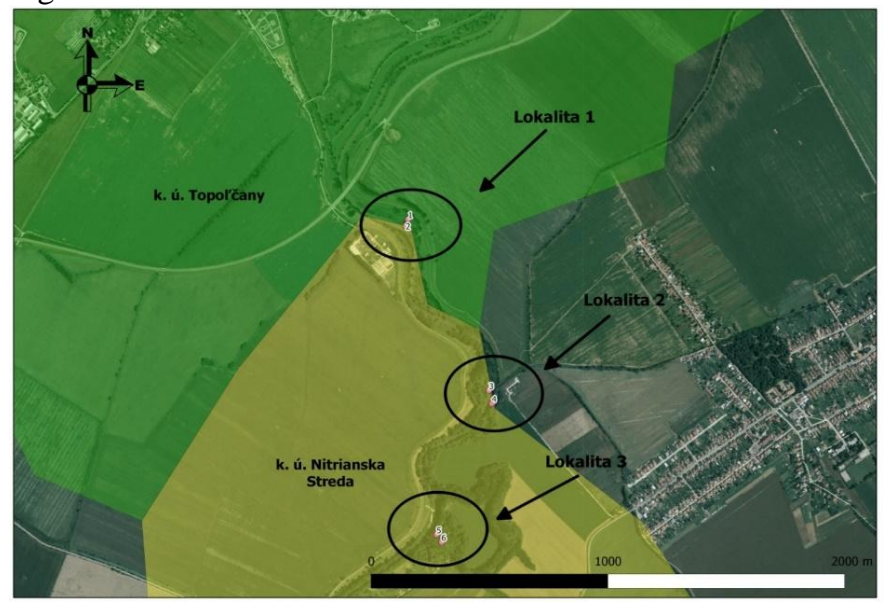

Used analytical methods are the most frequently used methods for monitoring and evaluating selected parameters in the process of soil analytical analysis. With their use it is possible to gain results that can be compared to limit values stated in valid legislation of SR (in the field of soil quality monitoring).

Within sampling, preparation and individual analytical determinations we derived and proceeded paralleled to:

$\checkmark$ out of knowledge of following authors - Nozdrovický et al. (2008), Hrivňáková et al. (2011), Fiala et al. (1999), Kobza et al. (2009), Linkeš et al. (1997), Zbíral et al. (2003), Watson, Brown (1998),

$\checkmark$ out of standards and regulations - STN ISO 10390 : 2005 a STN ISO 11466, Regulation of Soil Management of the Slovak Republic No. 338/2005 Coll. (No. 151/2016 Coll.), Act NR SR No. 220/2004 Coll.,

$\checkmark$ out of data from State Geological Institute of Dionýz Štúr SR for agricultural soil from the cadastral area of Topol'čany and Nitrianska Streda (year 2011),

$\checkmark$ out of provided information and internal materials of VUCHT, Inc. laboratory .

Within the evaluation of selected soil qualitative indicators we monitored following parameters of soil which can be divided into:

* Heavy metals: $\mathrm{Cu}, \mathrm{Cr}, \mathrm{Pb}, \mathrm{Cd}, \mathrm{Co}, \mathrm{Zn}, \mathrm{Ni}, \mathrm{As}, \mathrm{Hg}$

* Monitored $\mathrm{pH}$ : exchangeable soil reaction $(\mathrm{pH} / \mathrm{KCl})$

Choice of localities for the evaluation of heavy metals and its $\mathrm{pH}$ in model area (localities 1 to 3 ) depended on more criteria. One of them was aptly characterise "inundated area" of monitored watercourse - Nitra River. Another criteria was take into consideration purpose of soil use in monitored area as good 
as possible (forest soil, arable land and permanent grass cover). Localities and place of sampling are stated in Table 1 .

Table 1: Localities with place of soil sampling

\begin{tabular}{|c|c|c|c|c|c|c|c|c|}
\hline \multicolumn{9}{|c|}{ Sampling of soil samples from the floodplain of Nitra } \\
\hline & $\begin{array}{l}\text { symbol } \\
\text { of soil } \\
\text { sample }\end{array}$ & soil type & $\begin{array}{c}\text { site of } \\
\text { sampling }\end{array}$ & $\begin{array}{c}\text { village / } \\
\text { city }\end{array}$ & site location & river & $\begin{array}{c}\text { date of } \\
\text { sampling }\end{array}$ & GPS \\
\hline \multirow{2}{*}{ Locality 1} & P1 & $\begin{array}{c}\text { aluminum } \\
\text { sand }\end{array}$ & $\begin{array}{c}\text { Inundation } \\
\text { Territory }\end{array}$ & Topol'čany & $\begin{array}{c}\text { External } \\
\text { area }\end{array}$ & Nitra & $\begin{array}{c}12.03 . \\
2014\end{array}$ & \multirow{2}{*}{$\begin{array}{c}48.541956 \\
18.176058\end{array}$} \\
\hline & $\mathrm{P} 2$ & $\begin{array}{c}\text { aluminum } \\
\text { sand }\end{array}$ & $\begin{array}{c}\text { Inundation } \\
\text { Territory }\end{array}$ & Topol'čany & $\begin{array}{c}\text { External } \\
\text { area }\end{array}$ & Nitra & $\begin{array}{c}15.09 . \\
2014\end{array}$ & \\
\hline \multirow{2}{*}{ Locality 2} & P3 & $\begin{array}{c}\text { aluminum } \\
\text { sand }\end{array}$ & $\begin{array}{c}\text { Inundation } \\
\text { Territory }\end{array}$ & Topol'čany & $\begin{array}{c}\text { External } \\
\text { area }\end{array}$ & Nitra & $\begin{array}{c}12.03 . \\
2014\end{array}$ & \multirow{2}{*}{$\begin{array}{c}48.535360 \\
18.180527\end{array}$} \\
\hline & P4 & $\begin{array}{c}\text { aluminum } \\
\text { sand }\end{array}$ & $\begin{array}{c}\text { Inundation } \\
\text { Territory }\end{array}$ & Topol'čany & $\begin{array}{c}\text { External } \\
\text { area }\end{array}$ & Nitra & $\begin{array}{c}15.09 . \\
2014\end{array}$ & \\
\hline \multirow{2}{*}{ Locality 3} & P5 & $\begin{array}{c}\text { aluminum } \\
\text { sand }\end{array}$ & $\begin{array}{c}\text { Inundation } \\
\text { Territory }\end{array}$ & $\begin{array}{l}\text { Nitrianska } \\
\text { Streda }\end{array}$ & $\begin{array}{c}\text { External } \\
\text { area }\end{array}$ & Nitra & $\begin{array}{c}12.03 . \\
2014\end{array}$ & \multirow{2}{*}{$\begin{array}{r}48.530097 \\
18.179534\end{array}$} \\
\hline & P6 & $\begin{array}{c}\text { aluminum } \\
\text { sand }\end{array}$ & $\begin{array}{c}\text { Inundation } \\
\text { Territory }\end{array}$ & $\begin{array}{c}\text { Nitrianska } \\
\text { Streda }\end{array}$ & $\begin{array}{c}\text { External } \\
\text { area }\end{array}$ & Nitra & $\begin{array}{c}15.09 . \\
2014\end{array}$ & \\
\hline
\end{tabular}

\section{Sampling of soil samples}

Soil samples were taken with the use of soil probe with scraper (Regulation No. 338/2005 Coll. - No. 151/2016 Coll.). Soil samples were taken by approx. equal incisions (drill holes) within the sampling area stated above, namely by systematic grid as Nozdrovický et al. (2008) states. Essence of this way of sampling is division of land into systematically divided grid. It provides systematic covering of land surface and it helps to gain objective results. One mixture sample represents 25 soil incisions.

Figure 6: Soil sampling by the system of systematic grid

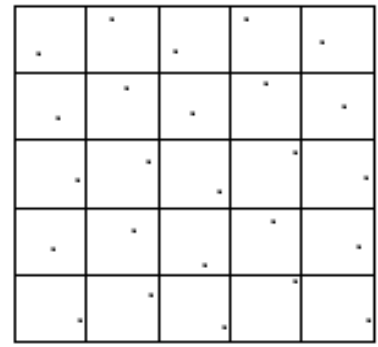

Soil was taken into glass containers with volume 0,51 , with marked information such as place of sampling, date, weather.

Depth of the sampling depended on concrete purpose of land use. During the sampling we used following procedures: 
* sampling on permanent grass cover are taken in depth of $10 \mathrm{~cm}$, not in whole soil profile (locality 1 ),

* sampling on forest cover are taken in depth $15-20 \mathrm{~cm}$ in mineral layer after uncovering of upper layer of humus (localities 2 and 3 ).

\section{Determination of soil reaction}

Principle of the method is: solution of neutral salt push hydrogen or aluminium and iron ions from exchangeable positions in adsorption soil complex. Activity change (concentration) of hydrogen ions is measured potentiometrically and it describes $\mathrm{pH}$ value. When measuring values of $\mathrm{pH} / \mathrm{KCl}$ in prepared soil solutions (Figure 7), we used an instrument $\mathrm{pH}$ meter $\mathrm{HI} 2110-\mathrm{pH}$ meter.

\section{Determination of soil extract in aqua regia - conventional total content}

Principle: prepared soil sample is extracted by compound $\mathrm{HCl}$ and $\mathrm{HNO}_{3}$ (3:1) so that it is left for 16 hours to stay at laboratory temperature and then it heats under reflux for 2 hours. It is needed to leave the extract to clarify and it fills up to former volume with $\mathrm{HNO}_{3}$. Content of trace elements in extract can be determined spectrometrically. For the determination of concentration content of particular elements - heavy metals, method ICP/OES (Inductively coupled plasma/Optical emission spectrometry) was used. It is one of the best analytical methods for determination of trace elements of various soil types, e.g. agriculture, food processing industry, organic materials, metals, biology etc. When measuring concentration content of monitored elements in prepared soil solutions, we used instrument SPECTROBLUE OES ICP SPECTROMETER - optical emission spectrometer with inductively coupled plasma. SPECTRO provides unmatched ICP-OES analyse of trace elements. Work procedure during analysis of prepared samples was realised according to internal materials and methodical instructions of VUCHT Inc. (Figure 8).

Figure 7: Used appatatus - before determination of $\mathrm{pH}$ insolution $\mathrm{KCl}$

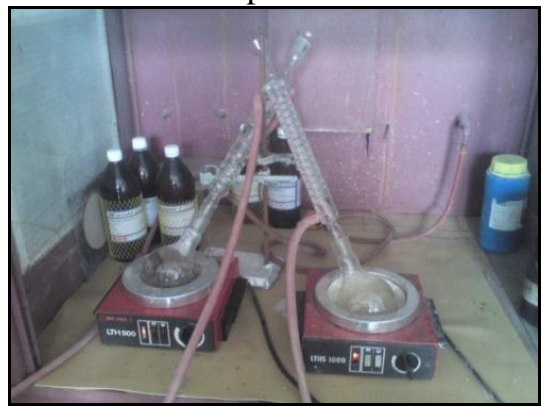

Photo: J. Straňák, 2014
Figure 8: Dissociation of elements in aqua regia - heating under reflux

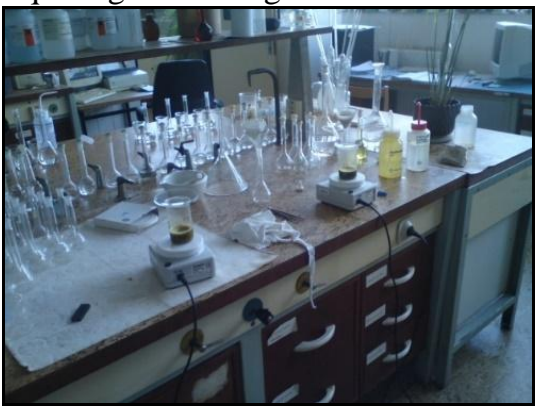

Photo: J. Straňák, 2014 


\section{Results}

Detected values of $\mathrm{pH}$ in soil samples were compared with relevant legislation according to Regulation MP SR 338/2005 Coll (new decree 151/2016 Coll for the monitored values has the same limits) because of confirmation of expected soil alkalinity in model area. Data of surrounding intensively agriculturally cultivated soils were taken into consideration too. We gained this data from the map portal of the State Geological Institute of Dionýz Stúr SR for agricultural soil from cadastral areas Topol'čany and Nitrianska Streda (year 2001) (Figure 9).

Figure 9: Detected values of $\mathrm{pH}$

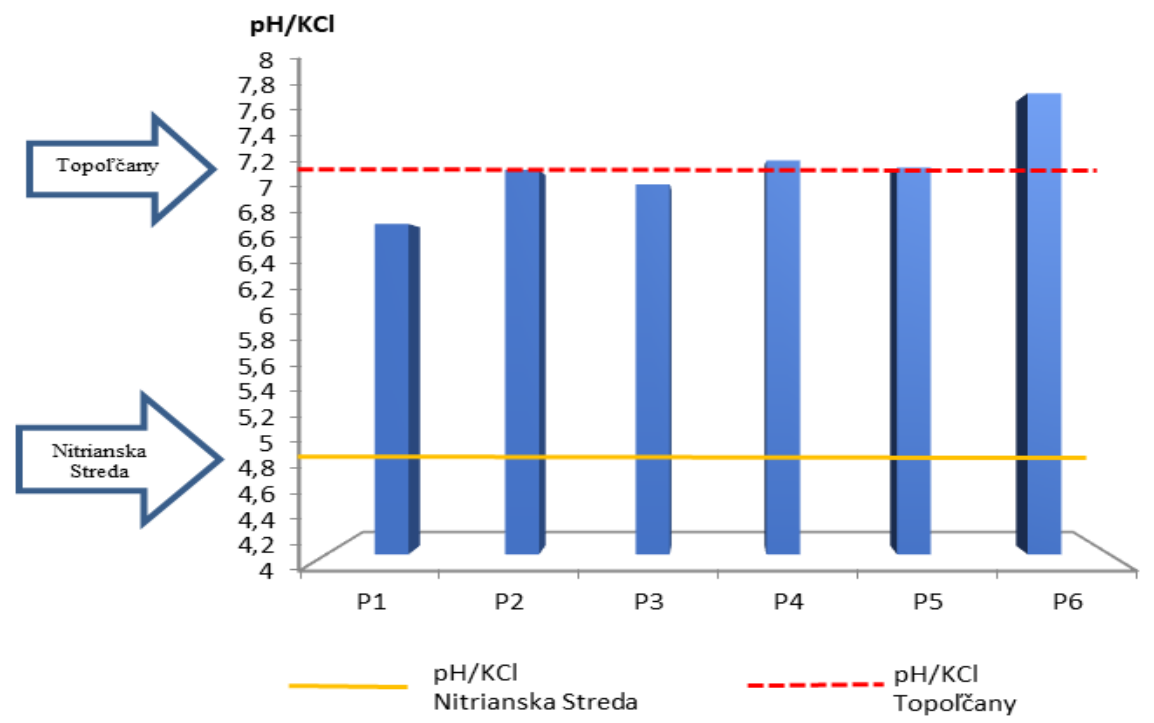

$\mathrm{pH}$ value was estimated as exchangeable soil reaction $(\mathrm{pH} / \mathrm{KCl})$. Detected soil reaction in selected localities fluctuated according to 338/2005 Coll. in range of neutral to high alkaline. Boundary of $\mathrm{pH}$ in monitored localities is 1.09 . The lowest value of $\mathrm{pH}$ (neutral) was detected in soil sample P1 with value 6.76. The highest detected $\mathrm{pH}$ value (highly alkaline) in soil sample P6 with value 7.85. In comparison to average value of soil reaction in cadastral area Topol'čany $(\mathrm{pH} / \mathrm{KCl}$ $=7.15$ ) values in monitored localities are in difference $0.05-1.95 \%$ in direction from neutral to alkaline soil reaction. Average value in cadastral area of Nitrianska Streda $(\mathrm{pH} / \mathrm{KCl}=4.89)$, in comparison to values of monitored localities, in difference $32.36-31.61 \%$ from highly alkaline to alkaline soil reaction. 
Table 2: Detected soil reaction according to legislation

\begin{tabular}{|c|c||c||}
\hline pH/KCl & $\begin{array}{c}\text { measured } \\
\text { values }\end{array}$ & soil reaction \\
\hline \hline P1 & 6.76 & neutral \\
P2 & 7.21 & alkaline \\
P3 & 7.09 & neutral \\
P4 & 7.29 & alkaline \\
P5 & 7.23 & alkaline \\
P6 & 7.85 & strongly \\
& & alkaline \\
\hline
\end{tabular}

Table 3: $\mathrm{pH}$ values according the regulation No. 338/2005 Coll.

\begin{tabular}{|c||c||}
\hline Kategory & $\begin{array}{c}\text { soil reaction } \\
(\mathbf{p H} / \mathrm{KCl})\end{array}$ \\
\hline \hline extremely acidic & $\leq 4,5$ \\
strongly acidic & $4,6-5,0$ \\
acidic & $5,1-5,5$ \\
slightly acidic & $5,6-6,5$ \\
neutral & $6,6-7,2$ \\
alkaline & $7,3-7,7$ \\
strongly alkaline & $>7,7$ \\
\hline \hline
\end{tabular}

Monitored heavy metals - Cd, Cr, Ni, Pb, Cu, Co, $\mathrm{Zn}, \mathrm{As}, \mathrm{Hg}$

Detected values of heavy metals in soil samples (Table 4) were compared with relevant legislation according to law 220/2004 Coll. because of confirmation of expected soil contamination (exceeding of limit values) in model area (Table 5). Data of surrounding intensively agriculturally cultivated soils were taken into consideration too. We gained this data from the map portal of the State Geological Institute of Dionýz Štúr SR for agricultural soil from cadastral areas Topol'čany and Nitrianska Streda (year 2011).

Values of concentrations, that were exceeded over the limit in the law No. 220/2004 Coll. are highlighted by red colour (Table 5).

Elements are graphically evaluated in cases where exceeding of value limits according to law 220/2004 Coll. was detected. 
Table 4: Detected concentrations of heavy metals in soil samples in $\mathrm{mg} / \mathrm{kg}$

\begin{tabular}{|c|c|c|c|c|c|c|}
\hline $\mathrm{mg} / \mathrm{kg}$ & P1 & P2 & P3 & P4 & P5 & P6 \\
\hline$C d$ & 0.9999 & 0.7999 & 0.7499 & 0.7999 & 0.7999 & 0.7999 \\
\hline $\mathrm{Cr}$ & 41.9959 & 130.9869 & 32.9967 & 63.9936 & 160.9839 & 103.9896 \\
\hline $\mathrm{Ni}$ & 20.9979 & 40.9959 & 12.9987 & 19.998 & 44.9955 & 32.9967 \\
\hline$P b$ & 31.9968 & 34.9965 & 25.9974 & 26.9973 & 24.9975 & 26.9973 \\
\hline $\mathrm{Cu}$ & 16.9983 & 77.9922 & 12.9987 & 11.9988 & 14.4985 & 14.9985 \\
\hline Co & 11.4988 & 9.9999 & 8.9991 & 9.9999 & 8.9991 & 8.9991 \\
\hline$Z n$ & 47.9952 & 58.9941 & 48.9951 & 45.9954 & 52.9947 & 51.9948 \\
\hline As & 0.2099 & 0.9699 & 0.1899 & 1.6998 & 1.9887 & 1.7098 \\
\hline $\mathrm{Hg}$ & 0.2299 & 0.0999 & 0.2999 & 0.2599 & 0.2399 & 0.2199 \\
\hline
\end{tabular}

Table: 5 Limit values according to law No. 220/2004 Coll. and averages of concentration contents in surrounding agricultural soil in model area according to SGIDŠ SR, 2011 in $\mathrm{mg} / \mathrm{kg}$

\begin{tabular}{|c|c|c|c|c|c|c|c|c|c|}
\hline Soil type/Limit & As & $C d$ & Co & $\mathrm{Cr}$ & $\mathrm{Cu}$ & $H g$ & $\mathrm{Ni}$ & $\mathrm{Pb}$ & $Z n$ \\
\hline $\begin{array}{c}\text { Sandy, } \\
\text { Aluminum sand }\end{array}$ & 10,00 & $\mathbf{0 , 4 0}$ & 15,00 & 50,00 & 30,00 & 0,15 & 40,00 & 25,00 & 100,00 \\
\hline Average for c. a. Topol'čany & 10,10 & 0,25 & $\mathbf{9 , 5 0}$ & $\mathbf{7 6 , 5 0}$ & 16,00 & 0,13 & 23,50 & 16,00 & 51,50 \\
\hline $\begin{array}{c}\text { Average for c.a. Nitrianska } \\
\text { Streda }\end{array}$ & 8,70 & 0,20 & $\mathbf{7 , 5 0}$ & 77,00 & 13,00 & 0,10 & 22,50 & 21,00 & 47,00 \\
\hline
\end{tabular}

Within monitored heavy metals in soil samples exceeding of limited values (contamination) was detected in cases of following elements: $\mathrm{Cd}, \mathrm{Cr}, \mathrm{Ni}$ and $\mathrm{Pb}$ (Table 6). In case of $\mathrm{As}, \mathrm{Co}, \mathrm{Cu}, \mathrm{Hg}$ and $\mathrm{Zn}$ elements, values were not exceeded in any of samples.

Table 6: Exceeded concentrations of monitored elements

\begin{tabular}{|c|c|c|c|c|c|}
\hline \multicolumn{2}{|c|}{$\begin{array}{c}\text { Selected elements } \\
(\mathrm{mg} / \mathrm{kg})\end{array}$} & $\mathbf{C d}$ & $\mathbf{C r}$ & $\mathbf{N i}$ & $\mathbf{P b}$ \\
\hline \multicolumn{2}{|c|}{ Limit $(\mathrm{mg} / \mathrm{kg})^{1}$} & $\mathbf{0 . 4 0 0 0}$ & $\mathbf{5 0 . 0 0 0 0}$ & $\mathbf{4 0 . 0 0 0 0}$ & $\mathbf{2 5 . 0 0 0 0}$ \\
\hline \multirow{2}{*}{ Locality 1 } & P1 & 0.9999 & 41.9959 & 20.9979 & 31.9968 \\
\cline { 2 - 6 } & P2 & 0.7999 & 130.9869 & 40.9959 & 34.9965 \\
\hline \multirow{2}{*}{ Locality 2 } & P3 & 0.7499 & 32.9967 & 12.9987 & 25.9974 \\
\cline { 2 - 7 } & P4 & 0.7999 & 63.9936 & 19.998 & 26.9973 \\
\hline \multirow{2}{*}{ Locality 3 } & P5 & 0.7999 & 160.9839 & 44.9955 & 24.9975 \\
\cline { 2 - 7 } & P6 & 0.7999 & 103.9896 & 32.9967 & 26.9973 \\
\hline
\end{tabular}




\section{Cadmium}

In all three monitored localities was value of $\mathrm{Cd}$ exceeded in range $87.48 \%$ - $149.98 \%$ more than limit value. Average from 6 taken samples in monitored area was $106.23 \%$ higher than their limit value. Average value in cadastral area Topol'čany fluctuated $37.5 \%$ under the limit value, but detected values are higher than this averageness 199.96 - 239.92\%. In cadastral area Nitrianska Streda average values for $\mathrm{Cd}$ was $50 \%$ under the limit value. Detected values in monitored localities fluctuated from detected averageness in cadastral area Nitrianska Streda more 274.95 - 349.95\% detected values of Cd (Figure 10).

Figure 10: Detected values of Cd

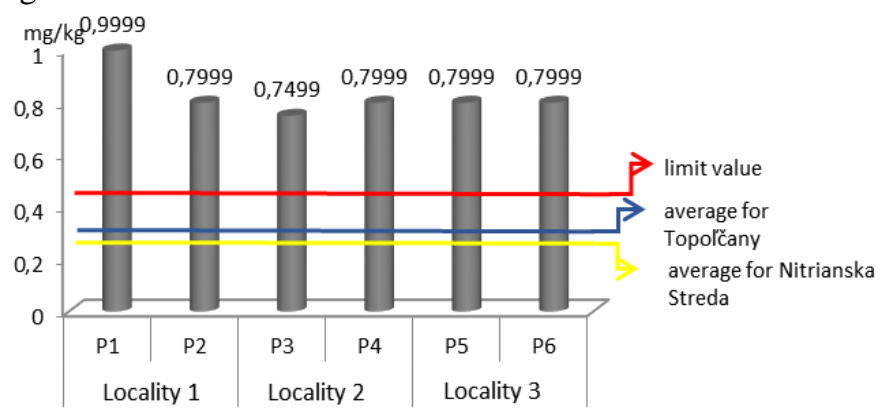

\section{Chromium}

In case of $\mathrm{Cr}$, limit value was exceeded in localities 2 and 3, namely in exceeding range $207.98 \%$ (P6) to $221.97 \%$ (P5) more. Averageness of all 6 taken samples in monitored area is $78.32 \%$ higher than limit value. In comparison to cadastral area Topol'čany, detected values fluctuated from $56.42 \%$ lower than average value up to $110.43 \%$ more than average value. In Nitrianska streda cadastral area, compared to averageness of this locality, detected values fluctuated in similar range as in Topol'čany cadastral area (Figure 11).

Figure 11: Detected values of $\mathrm{Cr}$

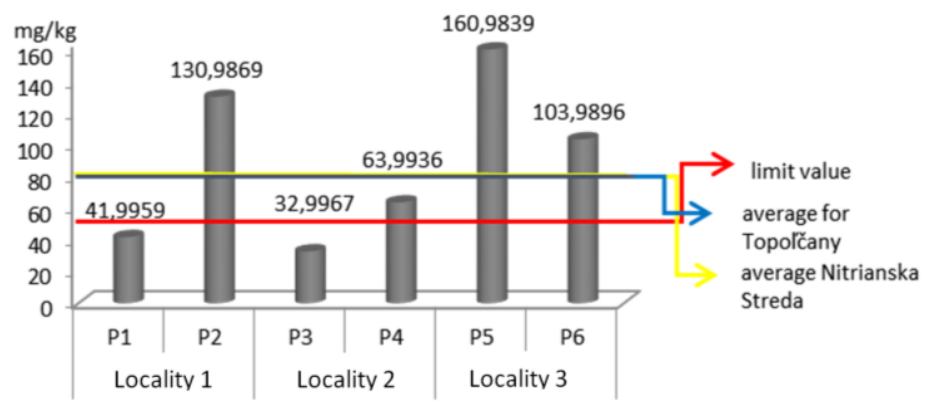




\section{Nickel}

$\mathrm{Ni}$ values were exceeded in locality 2 and 3 from $2.5 \%$ (P2) to $12.49 \%$ (P5). From the viewpoint of averageness of all taken soil samples from monitored area, limit value is not exceeded. In comparison to Topol'čany cadastral area, detected values of soil samples with $\mathrm{Ni}$ fluctuated in range from $44.67 \%$ under the averageness to $91.47 \%$ over the averageness. Soil samples of Nitrianska Streda cadastral area fluctuated in similar range as in Topol'čany cadastral area. Neither in cadastral area Topol'čany, nor Nitrianska Streda limit values were not exceeded by their average values (Figure 12).

Figure 12: Detected values of $\mathrm{Ni}$

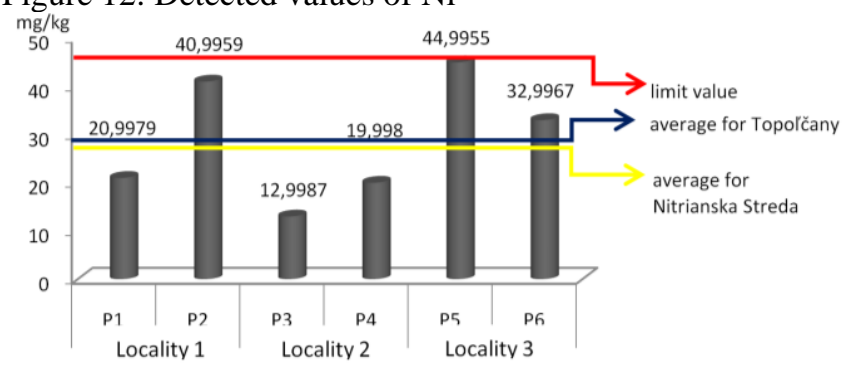

\section{Lead}

Detected values of $\mathrm{Pb}$ were exceeded in all three localities except for soil sample P5, namely in range $0.01 \%$ (P5) under the limit to $39.99 \%$ (P2) over the limit. From the point of view of averageness of all monitored soil samples in area of interest, limit value was exceeded by $14.66 \%$. In comparison to average value of cadastral area Topol'čany, range of monitored soil samples fluctuated from 56.23 to $118.73 \%$ over the averageness. In comparison to average value of cadastral area Nitrianska Streda, range of detected values fluctuated from 19.04 to $66.65 \%$ over the averageness. Average values in cadastral area Topol'čany and Nitrianska Streda were not exceeded with respect to limit given by law (Figure 13).

Figure 13: Detected values of $\mathrm{Pb}$

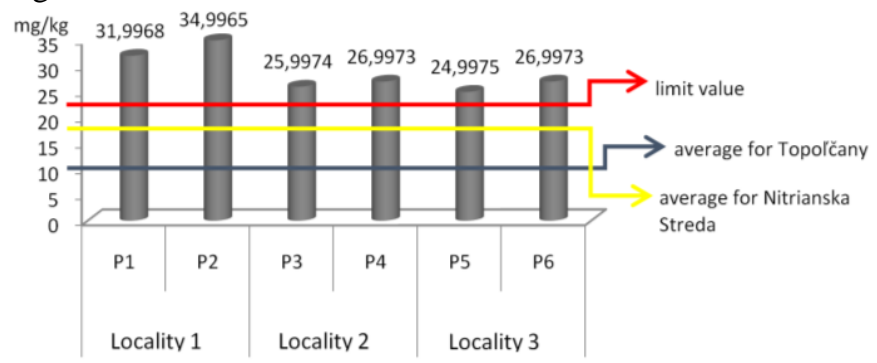




\section{Assessment of results}

Based on the assessment of limit values of monitored heavy metals out of all taken soil samples, the "lowest" soil contamination is in case of $\mathrm{Ni}$ and the "highest" in case of Cd. From the view point of monitored localities, the lowest concentration contents of heavy metals were detected in locality 2 in sampling place P3 - on March 2014. The most contaminated were locality 1 - P2 (September 2014) and locality 3 - P5 (March 2014). Concentration contents of Cd and $\mathrm{Pb}$ during the monitoring period of time were relatively balanced in all sampling places what can indicate relative stability of this elements in the soil, and so long-term contamination. Content of $\mathrm{Ni}$ and $\mathrm{Cr}$ concentration values were relatively variable during the monitoring period, what could indicate certain variability of this elements in soil (affected by Nitra River level its actual water quality). Based on gained data it is obvious that area is highly contaminated by $\mathrm{Cd}$. Research shows that in monitored stretch of Nitra River watercourse it is areal contamination by heavy metals. Last but not least, in case of monitored heavy metals $\mathrm{Cu}, \mathrm{Co}, \mathrm{Zn}$, $\mathrm{As}, \mathrm{Hg}$ concentration values were not determined, so that monitored area is not contaminated by heavy metals.

\section{Conclusion}

Because monitored elements $\mathrm{As}, \mathrm{Co}, \mathrm{Cu}, \mathrm{Hg}$ and $\mathrm{Zn}$ (heavy metals) belong among significant contaminants of soils in Slovakia, we can positively assess discovery, that significant part of monitored elements do not occur in the soil of monitored area. Based on gained results we can state that soil in inundated area of Nitra River (assessed stretch) is contaminated by elements - heavy metals - Cd, $\mathrm{Cr}, \mathrm{Ni}, \mathrm{Pb}$. It was proved by repeated soil analysis from identical localities (in time horizon of 6 months). Used analytical method takes into consideration presence of heavy metals in soil form the viewpoint of time length (dissociation in aqua regia). it proved the fact that metals are contained in inundated area of Nitra River relatively for a long time ( in case of $\mathrm{Cd}$ and $\mathrm{Pb}$ ). Within assessment of heavy metals it has to be pointed out that limit values which were used for comparison of Content concentrations of monitored elements serve mainly for agriculturally used land, not for soil in inundated areas of streams. As surrounding area of Nitra River is agriculturally used intensively, this assessment has good reason from the viewpoint of contamination level of monitored area.

\section{Identification of sources and forms of water contamination in model area}

For the gained results of qualitative assessment of soil parameters and based on characteristics of monitored indicators by Rapant, Vrana, Bodiš (1996); Kulveitová (2008); Chmielevská; et al. (2011) we can predict contamination source from three basic spheres:

Agriculture - Cd, Cr 
* use of organic and inorganic fertilizers in agriculture, use of pesticides in agriculture, draining of not adequately purified waste waters by soaking or draining into river flow, local leaking of pollutants into underground or surface waters and carrying of pollutants away into surface waters - wash off (inappropriate agricultural procedures).

Industry - $\mathrm{Cd}, \mathrm{Cr}, \mathrm{Ni}, \mathrm{Pb}$

* discharging of waste waters into surface water, emission decline of pollutants, situations when accident occurs - leakage of pollutants into underground water (oil substances, chemical substances) and inadequately secured areas of manipulation and warehouses with dangerous substances.

Municipal impact - $\mathrm{Cr}, \mathrm{Ni}, \mathrm{Pb}, \mathrm{Cd}$

* unprofessional usage of pesticides in domestic agriculture, illegal draining of waste waters (indirectly into underground and surface waters) and infusions of wastes placed in contravention of law - illegal dumps.

Detected contaminants and their compounds have negative effects on human as well as on environment:

* toxicity, carcinogenicity, contamination, transfer to organisms through the trophic chain, allergenicity, infectivity and mutagenicity (all in the long-term or intinzive load on the organism with the environment),

and so, for amelioration of actual state, it is needed to adopt following measures:

$\checkmark$ observe basic principles of protection and utilization of water and soil, and what is important, pass this measures directly on land,

$\checkmark$ during the realisation of activities, when there is possibility of leakage of substances dangerous for environment and water ecosystems, it is needed to adopt and/or observe existing methodologies, regulations and other procedures which prevent from this accidents,

$\checkmark$ design right management of water and soil in land,

$\checkmark$ apply right management of purification of water and public canalisation,

$\checkmark$ use procedure of right agricultural practice,

$\checkmark$ operations, where hazardous emissions are released into soil, air and water, it is needed to implements best available technologies,

$\checkmark$ minimise fertilising and usage of pesticides and try to use ecological forms, farming of agricultural land,

$\checkmark$ remove old environmental burdens in the shortest possible time,

$\checkmark$ observing of strategic documents and conceptual documents, mainly at local level.

Based on executed analyses in laboratory, we can appraise soil in delimited stretch of Nitra River as contaminated by following elements $\mathrm{Cd}, \mathrm{Cr}, \mathrm{Ni}$ and $\mathrm{Pb}$ with the highest exceeding of limit values of $\mathrm{Cd}$ according to legislation of SR. 
Nitra River is known by its poor water quality, what certainly affected the soil quality of inundated and/or monitored area too. Detected state of monitored area was affected (at present day or in the past - ecological accidents) by common factors caused by human activities, mainly industry (accidents and waste water from industry and municipal sphere), mining activities (release of heavy metals into environment, waste waters from these activities) and largely agriculture (fertilising of soil). On the ground of this research we assume that based on gained results we demonstrated contamination of selected elements and bad conditions of soil in inundated area of Nitra River in cadastral area Topol'čany and Nitrianska Streda.

\section{References}

ABOU-SHANAB, R. A. I. - ANGLE, J. S. - CHANEY, R. L. 2006. Bacterial inoculants affecting nickel uptake by Alyssum murale from low, moderate and high Ni soils. In Soil Biology and Biochemistry. ISSN 0038-0717, 2006, vol. 38, no. 9, pp. 2882-2889.

CANCES, B. et al. 2003. Metal ions in soil and its solution: experimental data and model result. In Geoderma. 2003, vol. 113, no. 3-4, pp. 341-355.

FIALA, K. et al. 1999. Záväzné metódy rozborov pôd (Čiastkový monitorovací systém - pôda). Bratislava: VUPOP, 1999. 142 s. ISBN 80-85361-55-8.

HANUŠIN, J. et al. 2000. Výkladový slovník termínov z trvalej udržatelnosti. Bratislava: Spoločnost' pre trvalo udržatel'ný život v SR, 2000. 158 s. ISBN 80968415-3-X.

HAVRLANT, M. - BUZEK, L. 1985. Nauka o krajině a péče o životni prostředí. Edice Učebnice pro vysoké školy. Praha: SPN, 1985. $126 \mathrm{~s}$.

HERNANDEZ-SORIANO C. M. 2012. Soil Health and land use management. [online]. INTECH : 2012, 344 p. [cit. 2014-06-20]. Dostupné na internete: $<$ http://www.intechopen.com/books/editor/soil-health-and-land-usemanagement>. ISBN 978-953-307-614-0.

HRAŠKO, J. - BEDRNA, Z. 1988. Aplikované pôdoznalectvo. 1. vyd. Bratislava: Príroda, 1988. $478 \mathrm{~s}$.

HRIVŇÁKOVÁ, K. et al. 2011. Jednotné pracovné postupy rozborov pôd. Bratislava: VUPOP Bratislava, 2011. 136 s. ISBN 978-80-89128-89-1.

CHMIELEVSKÁ, E. et al. 2011. Ochrana a využívanie prírodných zdrojov. Bratislava: EPOS Bratislava, 2011. 349 s. ISBN 978-80-8057-846-6.

JONES, R. J. A. et al. 2008. Environmental Assessment of Soil for Monitoring Volume V: Procedures \& Protocols. EUR 23490 EN/5, Luxembourg: Office for the Official Publications of the European Communities, 2008. 165 p. ISBN 978-92-79-09714-0. 
KOBZA, J. et al. 2009. Monitoring pôd SR. Aktuálny stav a vývoj monitorovaných pôd. Výsledky čiastkového monitorovacieho systému - Pôda za obdobie 2002 2006 (3. cyklus). Bratislava: VÚPOP, 2009. 200 s. ISBN 978-80-89128-54-9.

LINKEŠ, V. - PESTÚN, V. - DŽATKO, M. 1996. Príručka pre poživanie máp bonitovaných pôdno-ekologických jednotiek (Príručka pre bonitáciu polnohopodárskych pôd). 3. vyd. Bratislava: VUPOP, 1996. 104 s. ISBN 8085361-19-1.

LINKEŠ, V. et al. 1997. Monitoring pôd SR. Súčasný stav monitorovaných vlastností pôd 1992 - 96. Bratislava: VÚPÚ, 1997. 128 s. ISBN 80-85361-353.

MUDGAL, S. et al. 2014. Bio Intelligence Service (2014), Soil and water in a changing environment, Final Report prepared for European Commission (DG ENV), with support from HydroLogic.[online]. [cit. 2018-08-01]. Dostupné na internete: http://ec.europa.eu/environment/soil/pdf/Soil\%20and\%20Water.pdf $>$.

NOZDROVICKÝ, L. et al. 2008. Presné pôdohospodárstvo: implementácia s podporou informačných technológií a techniky. 1. vyd. Nitra: Slovenská pol'nohospodárska univerzita, 2008. $168 \mathrm{~s}$. ISBN 978-80-552-0123-8.

PASCUCCI, S. 2011. Soil contamination. INTECH. 168 s. ISBN 978-95-3307647-8.

RAPANT, S. - VRANA, K. - BODIŠ, D. 1996. Geochemický atlas Slovenska Čast' I: Podzemné vody. Bratislava: Geologická služba Slovenskej republiky, 1996. 127 s. ISBN 80-85314-67-3.

SASTRE, M. et al. 2002. Determination of $\mathrm{CD}, \mathrm{Cu}, \mathrm{Pb}$ and $\mathrm{Zn}$ in environmental samples: microwave-asiisted total digestion versus aqua regia and nitric acid extraction. In Analitica Chemica Acta. ISSN 0003-2670, 2002. vol. 462, pp. 5972.

STN ISO 10390 : 2005 - (Kvalita pôdy) Stanovenie pH pôdy.

STN ISO 11466 - (Kvalita pôdy) Extrakcia stopových prvkov rozpustných v lučavke.

SOUSA, A. et al. 2008. Validation of avoidance assays for the screening assessment of soils under different anthropogenic disturbances. In Ecotoxicology and Environmental Safety. 2008, vol. 71, pp. 661-670.

STYK, J. 2001. Problém t’ažkých kovov (kadmium, olovo, med', zinok) v pôdach Štiavnických vrchov a ich príjem trávnatými porastami. Bratislava: VUPOP, 2010. 136 s. ISBN 80-85361-90-6.

VOLTER, V. et al. 2011. Hodnocení púdy v podmínkach ochrany životného prostredí. Praha: Ústva zemndelske ekonomiky a informaci Praha, 2011. $480 \mathrm{~s}$. ISBN 978-80-86671-86-4.

VYHLÁS̆KA Ministerstva pôdohospodárstva Slovenskej republiky č. 338/2005 Z. z. ktorou sa ustanovujú podrobnosti o postupe pre odber pôdnych vzoriek.

WATSON, M. E. - BROWN, J. R. 1998. pH and Lime Requirement. pp. 13-16 Recommended Chemical Soil Test Procedures for the North Central Region. 
North Central Regional Research Publication No. 221 (Revised). 1998. Missouri Agricultural Experiment Station SB 1001. [online]. [cit. 2018-07-27]. Dostupné na : <http://ral.cfans.umn.edu/soil-analysis-and-methods/\#1>.

WITLINGER, V. - KOTLAS, P. 1999. Technika a životné prostredia. Bratislava: STU Bratislava, 1999. 139 s. ISBN: 80-227-1179-9.

ZÁKON NR SR č. 220/2004 Z. z. o ochrane a využívaní pol'nohospodárskej pôdy. ZBÍRAL, J. et al. 2003. Analýza pi̊d II. (Jednotné pracovní postupy). Brno: Ústrední kontrolní a zkušební ústav zemědelský, 2003. 154 s. ISBN 80-8654838-4.

ZHENLI, L. H. - XIAOE, E. Y. - STOFFELLA, P. J. 2005. Trace elements in agroecosystems and impacts on the environment. In Journal of Trace Elements in Medicine and Biology. 2005, vol. 19, no. 2-3, pp.125-140.

RNDr. Jozef Straňák, PhD.

Mgr. Zuzana Pucherová, PhD.

Ing. Marcela Domčeková

Ing. Iveta Vrábelová

Mgr. Katarína Ličková

Ing. Štefan Straňák

Ing. Maroš Záhorský

Department of Ecology and Environmental Science

Faculty of Natural Sciences

Constantine the Philosopher University in Nitra

Tr. A. Hlinku 1, 94974 Nitra, Slovak Republic

E-mail: jstranak@ukf.sk, zpucherova@ukf.sk, marcela.domcekova@ukf.sk, iveta.vrabelova@ukf.sk,_katarina.lickova@ukf.sk,_stefan.stranak@ukf.sk, maros.zahorsky@ukf.sk

\section{Ing. Andrej Píš}

Department of Poultry Science and Small Farm Animals

Faculty of Agrobiology and Food Resources

Slovak University of Agriculture in Nitra

Tr. A. Hlinku 2, 94976 Nitra, Slovak Republic

E-mail: Andrej.pis@uniag.sk

\section{Mgr. Kristína Šlágorová}

ZŠ s MŠ Král'a Svätopluka

Mierové námestie 10, 92551 Šintava, Slovak Republic

E-mail: kika.slagorova@gmail.com 